\title{
Cryptosporidium outbreaks associated with swimming pools
}

\author{
Steven Lam*, Bhairavi Sivaramalingam*, and Harshani Gangodawilage* \\ *Master of Public Health Program, University of Guelph, Guelph, ON. (All authors contributed equally to the paper.)
}

\begin{abstract}
Acute gastrointestinal illness is a common and preventable public health issue. Exposure to recreational water, such as in swimming pools, is a risk factor for acute gastrointestinal illness. Serious outbreaks of water-borne diseases in Canada are rare but can pose a significant threat to human health. Cryptosporidium is one of the most common infectious agents causing pool-related outbreaks. Pool fouling, lack of education and training, inadequate pool structures, and lack of disinfection equipment have been linked to outbreaks of Cryptosporidium. To minimize the burden of swimming pool related outbreaks, interventions should include pool structure alterations, increased surveillance and reporting of swimming pool associated diseases, and public education regarding the risk of swimming pool infections.
\end{abstract}

Key words: Cryptosporidium, regulations, risk factors, swimming pools, outbreaks.

\section{Introduction}

Acute gastrointestinal illness (AGI) is present in approximately 9\% of Canadians in any four-week period (Sargeant et al. 2008). The greatest risk of bacterial, viral, and protozoal AGI during the swimming season is due to exposure to recreational water (Denno et al. 2009). Recreational water includes hot tubs, lakes, rivers, oceans, water parks, wading pools, and swimming pools. Infectious agents such as bacteria, viruses, and protozoa may threaten the health or comfort of pool users. Characterization of these pathogens regarding source and mode of transmission may be an efficient way to reduce risks.

Enteric pathogens in pool water can be unintentionally ingested during swimming, increasing the risk of AGI. There is a $3 \%-8 \%$ increased risk of AGI after swimming (Sanborn and Takaro 2013). The most common pathogen in waterborne infections is Cryptosporidium (Craun et al. 2005); it is a protozoan that causes diarrheal illness and has been linked to recreational water illness in swimming pools (Craun et al. 2005; Hopkins et al. 2013; Mathieu et al. 2004). Cryptosporidium oocytes are highly resistant to chemical disinfectants used to purify recreational water sources (Boehmer et al. 2009).

We provide an overview of Cryptosporidium outbreaks associated with swimming pools, including transmission risk factors and populations at risk; an overview of the current regulatory standards in Canada; and suggestions to improve pool practises.

Corresponding author: Harshani Gangodawilage (email: hgangoda@ uoguelph.ca)

\section{Methods}

The PubMed database was used for the literature search, Textword searches for articles and abstracts were conducted using the following search terms alone or in combination: outbreaks, swimming pools, wading pools, Cryptosporidium, infection, and disease. The publications relating to swimming pool infections were selected. The reference lists of included studies were reviewed to identify relevant studies and were included in our bibliography. An environmental scan of federal and provincial policies on swimming pool regulations was conducted through a manual search of the websites of all provinces, using combinations of the terms "swimming pool, guidelines, regulations." The literature search was conducted in November and December 2013.

All papers identified by the search were initially screened for relevance using the title and (or) abstract. The inclusion criteria was published outbreaks from January 2000 to November 2013 that occurred in Canada and the United States. Literature was restricted to only those studies publishied English.

Infections other than those caused by Cryptosporidium are not addressed here to provide a higher focus for Cryptosporidium outbreaks. Giardia was not discussed in any detail in this document. Giardia infection is an important notifiable disease and is a source of swimming pool outbreaks. Giardia should be addressed exclusively in a future document.

Bibliographic data were entered into RefWorks, a web-based bibliography (http://www.refworks.com) to manage the bibliography. Eight articles were found to be relevant and were chosen for review. Pertinent information such as author, publication date, and type of study was extracted from each article and are summarized in Table 1. 
Table 1. Summary of articles.

\begin{tabular}{|c|c|c|c|c|}
\hline Authors & Type of infection & Location & Study size & Comments \\
\hline \multicolumn{5}{|l|}{ Review } \\
\hline $\begin{array}{l}\text { Craun et al. } \\
(2005)\end{array}$ & $\begin{array}{l}\text { Bacterial, } \\
\text { protozoal, viral }\end{array}$ & $\begin{array}{l}\text { Recreational } \\
\text { water }\end{array}$ & $\mathrm{n} / \mathrm{a}$ & $\begin{array}{l}\text { - Researchers reviewed causes of outbreak associated with } \\
\text { recreational water } \\
\text { - The most frequent agents were Cryptosporidium }(15 \%) \text {, } \\
\text { Pseudomonas }(14 \%) \text {, Shigella }(13 \%) \text {, Naegleria }(11 \%) \text {, } \\
\text { Giardia }(6 \%) \text {, and toxigenic E. coli }(6 \%) \\
\text { - Outbreaks caused by Cryptosporidium and Giardia were } \\
\text { primarily associated with treated water in swimming and } \\
\text { wading pools } \\
\text { - Records indicated that the pool met local health regulations }\end{array}$ \\
\hline \multicolumn{5}{|c|}{ Outbreak investigation } \\
\hline $\begin{array}{l}\text { Hopkins et al. } \\
\text { (2013) }\end{array}$ & Cryptosporidium & Water park & 12 cases & $\begin{array}{l}\text { - Pool fouling incident } 12 \text { November } 2010 \\
\text { - All cases visited the same water park between } 14 \text { and } 16 \\
\text { November } 2010 \\
\text { - UV disinfection system was offline on } 14 \text { November } 2010 \\
\text { which may have allowed for transmission to bathers }\end{array}$ \\
\hline $\begin{array}{l}\text { Mathieu et al. } \\
(2004)\end{array}$ & Cryptosporidium & $\begin{array}{l}\text { Swimming } \\
\text { pool }\end{array}$ & $\begin{array}{l}47 \text { cases } \\
57 \text { controls }\end{array}$ & $\begin{array}{l}\text { - Investigation of a cryptosporidiosis outbreak with } \\
>700 \text { clinical case patients } \\
\text { - Case-control study to determine risk factors } \\
\text { - Main risk factor was swimming in pool A } \\
\text { - Pool-based case-control study indicated that the highest } \\
\text { risk was related to exposure to pool water via the mouth } \\
\text { (OR } 5.1,95 \%, \text { CI } 2.112 .5) \\
\text { - Fecal accidents at the pool were documented } \\
\text { - Records indicated that the pool met local health regulations }\end{array}$ \\
\hline $\begin{array}{l}\text { Health Canada } \\
\text { (2004) }\end{array}$ & Cryptosporidium & $\begin{array}{l}\text { Swimming } \\
\text { pool }\end{array}$ & 33 cases & $\begin{array}{l}\text { - Questionnaire administered to all cases } \\
\text { - The water treatment system for each of the pools uses sand } \\
\text { filtration, ozonation, and chlorination and all were } \\
\text { operational throughout the likely exposure period of the } \\
\text { cases. } \\
\text { - There were two fecal accidents noted during exposure } \\
\text { period, and } 60 \% \text { of laboratory confirmed cases swam at } \\
\text { suspected pool complex within this period } \\
\text { - Age range of cases was } 0 \text { to } 36 \text { years, the median age was } 6 \\
\text { years. }\end{array}$ \\
\hline $\begin{array}{l}\text { Health Canada } \\
\text { (2002) }\end{array}$ & Cryptosporidium & & 59 cases & $\begin{array}{l}\text { - Case-control study where data were collected via telephone } \\
\text { interviews } \\
\text { - Age range of cases was } 2 \text { to } 45 \text { years, with median age of } 9 \\
\text { years } \\
\text { - Swimming was highly associated with getting diarrheal } \\
\text { illness }\end{array}$ \\
\hline $\begin{array}{l}\text { Boehmer et al. } \\
\text { (2009) }\end{array}$ & Cryptosporidium & $\begin{array}{l}\text { Swimming } \\
\text { pool }\end{array}$ & 21 cases & $\begin{array}{l}\text { - Cohort study among those who were disease free before } \\
\text { attending the swimming pool party } \\
\text { - Pool met the standard chlorination guidelines and used UV } \\
\text { light irradiation as a supplemental tool } \\
\text { - Risk for illness was higher in those who were in the } \\
\text { swimming pool } \\
\text { - Fecal accident was not reported to the pool management } \\
\text { - Example of Cryptosporidium outbreak in a well-maintained } \\
\text { pool }\end{array}$ \\
\hline
\end{tabular}


Table 1 (continued).

\begin{tabular}{|l|l|l|l|l|}
\hline Authors & Type of infection & Location & Study size & Comments \\
\hline $\begin{array}{l}\text { Wheeler et al. } \\
(2007)\end{array}$ & Cryptosporidium & Water park & 340 cases & $\begin{array}{l}\text { - Case-control study; data collected via interview } \\
\text { questionnaire } \\
\text { Age range for cases who visited the waterpark was } 1 \text { to } 69 \\
\text { years, out of which } 10 \% \text { were <4 years } \\
\text { Poor reporting and inadequate reporting of the illness by } \\
\text { employees of the water park }\end{array}$ \\
\hline $\begin{array}{l}\text { Causer et al. } \\
(2006)\end{array}$ & Cryptosporidium & Water park & 358 cases & $\begin{array}{l}\text { - Case-control study where cases and controls were matched } \\
\text { A standardized questionnaire, administered via telephone, } \\
\text { was used to collect data } \\
\text { Cryptosporidium was isolated in pool water samples } \\
\text { There was cross-contamination of two pools due to the } \\
\text { interconnected structure and sharing of filtration systems }\end{array}$ \\
\hline
\end{tabular}

\section{Risk factors of Cryptosporidium outbreaks}

In Canada and the United States, the two most common species of Cryptosporidium associated with outbreaks in swimming pools are Cryptosporidium parvum and Cryptosporidium hominis (Hopkins et al. 2013; Mathieu et al. 2004; Health Canada 2004; Polgreen et al. 2012; Boehmer et al. 2009; Wheeler et al. 2007; Causer et al. 2006). Many studies report that pool-fouling was a risk factor for infection with Cryptosporidium (Hopkins et al. 2013; Mathieu et al. 2004; Health Canada 2004). Hopkins et al. (2013) reported an outbreak investigation of Cryptosporidium in the Niagara region. Niagara Region Public Health declared an outbreak after four laboratory confirmed cases of Cryptosporidium were linked to visiting the same water park. Investigators found that there had been a solid stool fecal accident prior to the outbreak. The accident was cleared up using the proper guidelines set out by the Centre for Disease Control (2010). In addition to the accident, the ultraviolet (UV) disinfection system was offline for a day which may have contributed to water contamination. Health Canada (2004) reported another swimming pool outbreak in Surrey, BC, that detected Cryptosporidium oocytes using sample water testing. Contamination of the pool was traced back to two poolfouling incidents during the exposure period. In addition, Cryptosporidium oocytes were detected in the stool of one employee who was in the pool on a daily basis. The employee had worked throughout the symptomatic period. The water treatment system for each of the pools uses sand filtration, ozonation, and chlorination; all were operational throughout the likely exposure period of the cases. Similar outbreaks have also occurred in the United States. A pool-fouling related outbreak of Cryptosporidium parvum in Ohio was investigated by Mathieu et al. (2004). At least five fecal accidents at the pool were documented and records indicated that the pool met local health regulations. The findings of these investigations indicate that although swimming pools are adequately operated and maintained in compliance with existing standards and guidelines, they may still be contaminated with Cryptosporidium oocytes.

Outbreaks may also be due to lack of education and awareness about infectious diseases among pool managers, staff, and users. In an outbreak in California, the life guards on duty were sick and no measures were taken to prevent them from working (Wheeler et al. 2007). The sick life guards were in the water while they were symptomatic and likely contaminated the water. The lack of education and a clear policy to keep lifeguards and employees out of the water while sick led to this incident (Wheeler et al. 2007).

Another contributing factor to the spread of pathogens is the interconnected design of pools and shared filtration systems, leading to the cross contamination of pools (Causer et al. 2006). The water park described by Causer et al. (2006) had a toddler pool, lap pool, and a "lazy river". The filtration systems for the toddler pool and lap pool were interconnected (Causer et al. 2006). Although the reported diarrheal incidents happened only in the toddler pool, Cryptosporidium oocytes were detected in both the lap pool and the toddler pool water samples.

\section{Transmission routes}

Ingesting water or being splashed with water from the recreational water source was significantly associated with becoming infected with Cryptosporidium (Boehmer et al. 2009). In one outbreak investigation, there was a statistically significant association between getting sick and having water in the mouth or standing under a sprinkler (OR 5.1, 95\%, CI 2.1-12.5) (Mathieu et al. 2004). Similarly in a study from California, Cryptosporidium illness was associated with having water splashed on the face or having the head dunk into the water while on the waterslide (OR 24.0, 95\% CI 3.1-187.9) (Wheeler et al. 2007). In a study from Manitoba, persons who immersed their heads into the water were more likely to become ill than those who did not (OR 6.5, 95\% CI 2.6-24.9) 
(Health Canada 2002). From these studies, it is suggested that the route of transmission for Cryptosporidium is oral ingestion of contaminated water or contact with contaminated water (Health Canada 2002). Person-to-person spread of infection has also been reported in outbreaks (Health Canada 2004; Boehmer et al. 2009; Bouzid et al. 2013). Boehmer et al. (2009) reported secondary attack rate of $25 \%$ in Atlanta within household members, indicating the high infectivity of Cryptosporidium (Boehmer et al. 2009).

\section{Population at risk}

Cryptosporidium attacks persons of all ages; however, children are affected by the illness more often than adults or the elderly (Mathieu et al. 2004; Polgreen et al. 2012; Causer et al. 2006). Polgreen et al. (2012) reported that although subjects in the cases ranged from 0 to 88 years of age, about $47 \%$ of cases were observed among children under the age of 9 (Polgreen et al. 2012). Children have been reported to be the most important reservoir for Cryptosporidium even when they are asymptomatic (Bouzid et al. 2013). Having contact with children, daycare, or another infected person are associated with the illness (Mathieu et al. 2004; Causer et al. 2006), because a person coming in contact with children may be at risk of secondary infections. Although the gender distribution of infection was even among children, females were more impacted than males among adults (Polgreen et al. 2012). This pattern may be explained by the common practice of mothers being involved in changing diapers and caring for sick children, resulting in a secondary infection.

Children may be most affected by Cryptosporidium infection as they are the most frequent users of water parks. Furthermore, children may be more susceptible to illness as they generally tend to have a weaker immune system than adults (Bouzid et al. 2013). Awareness among children may be lower than adults regarding infection spread and the importance of proper sanitation; because of this, they are more likely to ingest water while engaging in these activities and may contribute to fouling activities in the water.

The size of the water source may also determine risk of infection. In a statewide outbreak investigation carried out in Iowa, investigators found that smaller camp pools in comparison with larger camp pools were a risk factor for Cryptosporidium infection (Polgreen et al. 2012). The reasons for this may be due to poor implementation control measures and lack of resources in a small camp pools compared with the larger ones (Health Canada 2004). Furthermore, pools that serve heterogeneous populations are at a higher risk than pools that serve more homogeneous or isolated populations (Polgreen et al. 2012).

\section{Swimming pool regulations in Canada}

Of the Cryptosporidium outbreaks indicated in this report, most pool facilities were following local pool operating regulations, yet they still managed to have contaminated pool water. An environmental scan was conducted to assess the current provincial swimming pool operating standards in
Canada to determine if these regulations are adequate to ensure public safety. Of the ten provinces, only seven have provincial legislation on the operation of swimming pools (Government of British Columbia 2010; Government of Ontario 2007; Government of Saskatchewan 2006; Government of Prince Edward Island 2005; Government of Quebec 2006; Government of Alberta 2006; Government of Manitoba 1997). Newfoundland and Labrador has pool guidelines (Government of Newfoundland and Labrador 2004), whereas Nova Scotia recently retired their 1987 guidelines as they were out of date (Nova Scotia 1998), and New Brunswick has no accessible legislation or guidelines regarding pools (Nova Scotia 1998; Recreation Nova Scotia 2013). Regulations governing Ontario, British Columbia, Alberta, Manitoba, Saskatchewan, and Prince Edward Island are all similar in terms of acceptable standards of $\mathrm{pH}$ level, alkalinity, and free available chlorine. However, there are variations in the level of detail prescribed in other aspects of pool operation. Noticeable differences stem from the classification of pools, acceptable bacteriological water quality, and record keeping.

British Columbia, Alberta, Manitoba, Saskatchewan, and Prince Edward Island all regulate wading pools under their public pool regulations. However, the Ontario Regulation 565 of R.R.O 1990 under the Health Promotion and Protection Act, does not currently regulate wading pools (any pool with a depth of $0.75 \mathrm{~m}$ or less) or splash pads (Government of Ontario 2007), as it does not deem wading pools as an equivalent risk to larger sized pools. In 2008, the Ontario Public Health Association advocated for legislative action to create proper guidelines for wading pool operation with no avail (Ontario Public Health Association 2008). This is a major public health concern as waterborne outbreaks of Cryptosporidium related to the use of splash pads in the United States and Canada have been increasing (Pintar 2008). Until new legislation is brought in, the Ontario Ministry of Health and Long Term Care has created a guidance document for the operation of nonregulated recreational water facilities to assist public health inspectors (Ontario Ministry of Health and Long-Term Care 2010).

The acceptable bacteriological level of swimming pool water is not always legislated by provinces. Ontario, Saskatchewan, and British Columbia have vague statements such as "the microbiological quality of pool water must not present a risk to the health of pool patrons" in their standards (Government of British Columbia 2010). When no detailed water quality standards are legislated, public health authorities refer to scientific literature to decide upon acceptable levels of contamination (Public Health Ontario 2013).

Provinces that do have pool operating legislation require that all pool operators keep a record of daily inspections, which typically consists of recording $\mathrm{pH}$ levels, free chlorine, injuries, and equipment breakdown. British Columbia has an additional requirement where operators must record all occurrences of contamination by feces or vomit (Government of British Columbia 2010). This may be useful in the incidence of an outbreak and allow for mitigation strategies to be implemented quickly. 


\section{Recommendations}

The current review suggests that prevention and removal of Cryptosporidium at the source (i.e., swimming pools) would be the most effective means of reducing Cryptosporidium outbreaks. The following recommendations outline several ways of intervening at the source.

\section{Improve pool structure and disinfection equipment (or engineering control measures)}

Causer et al. (2006) and Mathieu et al. (2004) suggested the need for infrastructure modifications to reduce pool water contamination. The interconnection of children's wading pools and adult pool filtration systems pose a concern because it may allow for contamination to spread. If multiple pools are interconnected, alteration of the pool design to separate pool filtration systems is recommended. Filtration is a major component of all pools and can be considered a defence against Cryptosporidium as these parasites are highly resistant to chlorine (Mathieu et al. 2004; Korich et al. 1990). However, not all filters are designed to be equally effective at removing Cryptosporidium oocytes because of their small size (Mathieu et al. 2004). Local public health units should consider providing pool operators with guidelines on the effectiveness of the different types of pool filters available (sand, anthracite, diatomaceous earth, or cartridge). For further protection, pool operators may consider installing a UV disinfection system. UV disinfection is very effective at inactivating Cryptosporidium oocytes (Boehmer et al. 2009).

\section{Education programs for pool operators and bathers}

The results of this evidence review suggest that more careful monitoring and control measures are especially needed in areas where children swim. There is lack of education among swimming pool operators and users about communicable diseases. Some of the factors that need to be emphasized include immediate and sufficient response to fecal contamination and removal of sick people from the pool. The outbreaks indicated in this report illustrate that even with adequate pool operating conditions, if these risk factors are present, an outbreak can still occur. Implementation of education programs for pool operators, managers, and users may reduce disease transmission.

\section{Further research into detection methods}

If Cryptosporidium remains undetected in pool water it may survive for up to 6.7 days at a free available chlorine concentration of $1 \mathrm{mg} / \mathrm{L}$ and $\mathrm{pH}$ of 7.5 (Simcoe Muskoka District Health Unit n.d.), allowing the parasite to infect many bathers. Water quality testing often involves analysis of Escherichia coli and coliforms to detect fecal contamination, which may indicate the presence of other more harmful pathogens; however, it is considered to be less effective as an indicator for protozoans that are more resistant to the disinfection process (Health Canada 2012). The absence of E. coli or coliforms does not necessarily indicate the absence of Cryptosporidium (Health Canada 2012). Currently there are no accurate methods to detect Cryptosporidium. More research needs to be done to find a suitable indicator organism for this parasite. The research findings would help enhance monitoring and surveillance of Cryptosporidium outbreaks in pools.

\section{Gaps and limitations}

A large number of Cryptosporidium outbreaks have been reported in the United States; however, studies of Cryptosporidium outbreaks in Canadian recreational water pools are limited. This limits the identification of potential risk factors for transmission of Cryptosporidium in Canadian pools. Another limitation of the current evidence review is that gray literature and secondary articles were not included in studying the characteristics of outbreaks. Additionally, because this review mainly consisted of outbreak investigations, the sample sizes were small, thus giving large confidence intervals. Therefore, the precision and certainty of the measures of association of the studies included were low. This review is also limited to outbreaks that were published between 2000 and 2013.

\section{Conclusion}

As swimming pools become increasingly popular for leisure during the summer months, public health will continue to face ongoing challenges of swimming pool associated infections and outbreaks. Cryptosporidium is a common agent of AGI outbreaks and risk management measures must be put in place to ensure that the risk of AGI is reduced. Educational programs that target parents, children, and pool employees should emphasize good hygiene practices, the need to avoid swimming when infected with AGI, and the understanding of the risks of communicable diseases in swimming pools. Educational programs must also target swimming pool facilitators regarding fecal accident response and monitoring. Provincial governments should standardize acceptable bacteriological levels for pool water and require the recording of fecal accidents. A major concern is the need to implement wading pool regulations in Ontario, as children frequently swim in wading pools and are most susceptible to AGI.

\section{References}

Boehmer, T.K., Alden, N.B., Ghosh, T.S., and Vogt, R.L. 2009. Cryptosporidiosis from a community swimming pool: Outbreak investigation and follow-up study. Epidemiology and Infection, 137(11): 1651-1654. DOI: 10.1017/S0950268809002696.

Bouzid, M., Hunter, P.R., Chalmers, R.M., and Tyler, K.M. 2013. Cryptosporidium pathogenicity and virulence. Clinical Microbiology Reviews, 26(1): 115-134. DOI: 10.1128/CMR.00076-12.

Causer, L.M., Handzel, T., Welch, P., Carr, M., Culp, D., Lucht, R., et al. 2006. An outbreak of Cryptosporidium hominis infection at an illinois recreational waterpark. Epidemiology and Infection, 134(1): 147-156. DOI: 10.1017/S0950268805004619. 
Centre for Disease Control. 2010. Fecal incident response recommendations for pool staff. Retrieved from website: http://www.cdc. gov/healthywater/pdf/swimming/pools/fecal-incident-response-re commendations.pdf.

Craun, G.F., Calderon, R.L., and Craun, M.F. 2005. Outbreaks associated with recreational water in the United States. Int J Environ Health Res, 15(4): 243-62. DOI: 10.1080/09603120500 155716.

Denno, D.M., Keene, W.E., Hutter, C.M., Koepsell, J.K., Patnode, M., Flodin-Hursh, D., Stewart, L.K., Duchin, J.S., Rasmussen, L., Jones, R., and Tarr, P.I. 2009. Tri-county comprehensive assessment of risk factors for sporadic reportable bacterial enteric infection in children. J Infect Dis, 199(4): 467-76. DOI: 10.1086/596555.

Government of Alberta. 2006. Swimming pool, wading pool and water spray park regulation, Alberta Regulation. 293/2006. Public Health Act.

Government of British Columbia. 2010. Pool regulation, B.C. Reg. 296/2010. Public Health Act.

Government of Manitoba. 1997. Swimming pools and other water recreational facilities regulation, Manitoba Regulation. 132/97. Public Health Act.

Government of Newfoundland and Labrador. 2004. Department of Health and Community Services. Public pools and water quality guidelines and record keeping standards. St. John, NL.

Government of Ontario. 2007. Public pools, R.R.O. 1990, Reg. 565. Health Protection and Promotion Act.

Government of Prince Edward Island. 2005. Swimming pool and waterslide regulations, P.E.I. Reg. EC93/01. Public Health Act.

Government of Quebec. 2006. Regulation respecting water quality in swimming pools and other artificial pools, 2006 G.O.Q. 2, 3930. Environmental Quality Act.

Government of Saskatchewan. 2006. Swimming pool regulations, 1999, R.R.S. c. P-37.1 Reg. 7.

Health Canada. 2002. Outbreak of diarrheal illness in attendes at a Ukrainian dance festival, Dauphin, Manitoba - May 2001. Canada communicable disease report, 28(17): 141-148.

Health Canada. 2004. An outbreak of Cryptosporidium parvum in a Surrey pool with detection in pool water sampling. Canada communicable disease report, 30(7): 61-65.

Health Canada. 2012. Guidelines for Canadian recreational water quality. Ottawa, ON: Health Canada.

Hopkins, J., Hague, H., Hudgin, G., Ross, L., and Moore, D. 2013. An Outbreak of Cryptosporidium at a Recreational Water Park in Niagara Region. Canada J Environ Health, 75(9): 28-33.
Korich, D.G., Mead, J.R., Madore, M.S., Sinclair, N.A., and Sterling, C.R. 1990. Effects of ozone, chlorine dioxide, chlorine, and monochloramine on Cryptosporidium parvum oocyst viability. Appl Environ Microbiol, 56(5): 1423-1428.

Mathieu, E., Levy, D.A., Veverka, F., Parrish, M.K., and Sarisky, J. 2004. Epidemiologic and environmental investigation of a recreational water outbreak caused by two genotypes of Cryptosporidium parvum in Ohio in 2000. Am J Trop Med Hyg, 71(5): 582-589.

Nova Scotia. 1998. Safety supervision guidelines for public swimming pools in Nova Scotia. Halifax, NS: Government of Nova Scotia.

Ontario Ministry of Health and Long-Term Care. 2010. Operating procedures for non-regulated recreational water facilities guidance document.

Ontario Public Health Association. 2008. Resolution 3 regulation and inspection of splash pads and other similar forms of wet recreation. Retrieved from website: http://opha.on.ca/getmedia/ da7ed0bd-085d-42c3-ade9-c97d7275284e/2008-03_res.pdf.aspx? ext $=$.pdf.

Pintar, K. 2008. Cryptosporidium and Giardia. ROWPH Training Workshop. Lecture conducted from Waterloo, Ontario.

Polgreen, P.M., Sparks, J.D., Polgreen, L.A., Yang, M., Harris, M.L., Pentella, M.A., et al. 2012. A statewide outbreak of Cryptosporidium and its association with the distribution of public swimming pools. Epidemiology and Infection, 140(8): 1439-1445. DOI: $10.1017 /$ S0950268811000987.

Public Health Ontario. 2013. Public health inspector's guide to the principles and practices of environmental microbiology. Toronto, ON: Queen's Printer for Ontario.

Recreation Nova Scotia. 2013. 1987 public swimming pool guidelines. Retrieved from http://www.recreationns.ns.ca/1987-public-swimm ing-pool-guidelines/ [Accessed 15 November 2013].

Sanborn, M., and Takaro, T. 2013. Recreational water-related illness. Canadian Family Physician, 59: 491-495.

Sargeant, J.M., Majowicz, S.E., and Snelgrove, J. 2008. The burden of acute gastrointestinal illness in Ontario, Canada, 2005-2006. Epidemiol Infect, 136(4): 451-60. Epub 2007 June 13. DOI: $10.1017 /$ S0950268807008837.

Simcoe Muskoka District Health Unit. n.d. Public pool manual for operators. Retrieved from website: http://www.simcoemuskokahealth.org/libraries/jfy_businesses/pool_operators_manual.sb.

Wheeler, C., Vugia, D.J., Thomas, G., Beach, M.J., Carnes, S., Maier, T., et al. 2007. Outbreak of cryptosporidiosis at a california waterpark: Employee and patron roles and the long road towards prevention. Epidemiology and Infection, 135(2): 302-310. DOI: $10.1017 /$ S0950268806006777. 